\begin{tabular}{c} 
International Journal of Engineering \& Technology, $7(3.34)(2018) 382-384$ \\
International Journal of Engineering \& Technology \\
SPC \\
Website $:$ www.sciencepubco.com/index.php/IJET \\
Research paper \\
\hline
\end{tabular}

\title{
Productivity Improvement and Cost Reduction in Hydraulic Cylinders
}

\author{
Gayathri $\mathbf{N}^{*}$, Karthick $\mathbf{N}^{2}$, Shanmuganathan $\mathbf{V} \mathbf{K}^{3}$, Adhithyan $\mathbf{T} \mathbf{R}^{4}$, Madhan Kumar $\mathrm{T}^{5}$, Gopalakrishnan $\mathbf{J}^{6}$ \\ 1, 2,4,5,6 Department of Mechanical Engineering, Vel Tech High Tech Dr.Rangarajan Dr.Sakunthala Engineering College, \\ Chennai - 600062, India \\ ${ }^{6}$ Department of Aeronautical Engineering, Jaya Engineering College, Chennai - 602024, India \\ *Corresponding author E-mail: gayathrimechanical@gmail.com
}

\begin{abstract}
This paper is aimed to analyze the current status and processes carried out in production of hydraulic cylinders and to optimize the manufacturing methods to increase the production volumes and to reduce the cost of hydraulic cylinders. KAIZEN 10 step methodology is the tool used for improvement. Required data was retrieved from reports, daily logs and job sheets. Then it was analyzed to find bottlenecks in production lines and start working on solutions to improve productivity. Thus fluctuating customer requirements can be met and industries can sustain with competitor entries.
\end{abstract}

Keywords: Cost reduction; Hydraulic Cylinder; Kaizen; Loss; Productivity.

\section{Introduction}

\subsection{Hydraulic Cylinder:}

A double acting hydraulic cylinder is a cylinder in which the pressurized hydraulic fluid is used to move the pistons in the cylinder. A hole is provided in one end of the cylinder to connect the piston in cylinder to an external mechanism. The piston rod is fitted with gland to prevent the leakage of fluid to the other side. It has a port at the each end, filled with fluid for extension and retraction of piston. A hydraulic cylinder is an actuator used for applying unidirectional force through a unidirectional stroke.

\subsection{Kaizen:}

Kaizen is Japanese which means continuous improvement, word 'Kai', means 'Continuous' and 'Zen' means 'Improvement'. In business, kaizen means activities that continuously improve all functions. It is a long-term approach that systematically looks to achieve small changes in processes and to improve efficiency and quality.

\subsection{Problem Background:}

The main problem of production of hydraulic cylinder is low order from the client and due to the low order the work idle occurs. The cost of the production also increases. The cost of the cylinder is low in market compared to the procedure used to produce the cylinder.

\section{Proposed Methodology}

"Kaizen" 10 Step Methodology
1. Select the topic and type of loss

2. Organize the Focused Improvement group

3. Measure the current loss

4. Organize activities for the group and plan analysis steps

5. Specify improvement factors and set objectives

6. Analyze factors and set corrective \& improvement actions

7. Implement improvement actions

8. Check and confirm effectiveness

9. Implement lock-up actions

10. Future actions.

\section{STEP 1: Select Topic and Type of Loss:}

Topic: productivity Improvement and cost reduction in Hydraulic cylinder.

Types of Loss:

The losses that are considered here are:

1. Financial loss

2. Idle hours of labours

\section{STEP 2: Focused Improvement Group:}

Based on the above flow chart and initial research, we have constrained to major specific department to continue further observation.

Technology Department:

- Document Preparation

- Document flow process

- Material flow Process

- Work balance

Production Department:

- Manual operation - (Disassembly \& Assembly)

- Verification Process

- Material flow and Logistic

- Employer Skill 
- Employer Presence and Engagement

\section{STEP 3: Current Loss Management:}

List of Losses:

- Low orders from client.

- Idle hours of the labors, because of low orders.

- $\quad$ Financial loss - (material and operational cost)

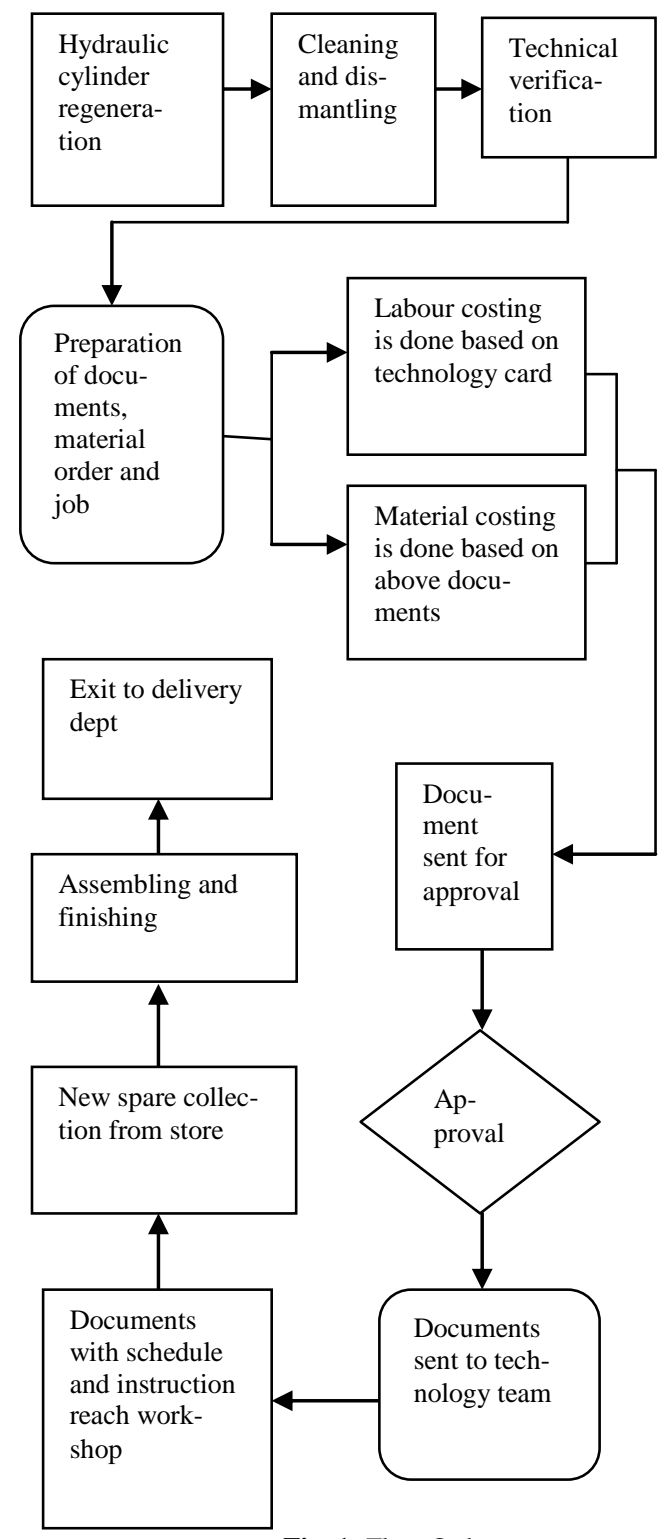

Fig. 1: Flow Order

\section{STEP 4: Organize Activities for the Group and Plan Analysis Steps:}

Based on the loss measurement from step 3, It is known that low orders is one of the key reason, directly impact efficiency, service cost and idle time, delivery time which is also consider to be major loss on this project

In order to reduce this loss in a step by step manner on focusing sustainable solution for the problem, we have planned and perform a technical analysis at two major department involved.

\section{STEP 5: Specify Improvement Factors and Set Objectives:}

Technology Department:

1. Document Preparation - This include technical specification, standards, drawings and material used.
2. Document flow process - Flow of document at each step(material, production, client approval)

3. Work balance - This include total number of orders completed by technologist per month.

4. Equipment's \&Tools - This include hardware and software being used for preparation.

Production Department: (Identified Factors)

1. Manual operation - This include Disassembly, Assembly, machining and cleaning

2. Verification process - Inspection on dissemble hydraulic cylinder

3. Material flow and Logistic - Client approval on material and material delivery.

4. Employer Presence - Employer presence on the work shop for hydraulic cylinder orders.

\section{Step 6: Analyze Factors and Set Corrective and Improvement Actions:}

Parts selected for deep analysis are as follows:

\begin{tabular}{|l|l|l|l|l|l|}
\hline S.No. & Part Name & Image & Tech No. & $\begin{array}{l}\text { Rece- } \\
\text { ived }\end{array}$ & $\begin{array}{l}\text { Time } \\
\text { Hr: } \\
\text { Min }\end{array}$ \\
\hline 1 & $\begin{array}{l}\text { Cylinder } \\
\text { Sleeves }\end{array}$ & 522474 & 1 & 50.9 \\
\hline 2 & Piston Rod & SOg & 322478 & 2 & 92.46 \\
\hline
\end{tabular}

Step 6.1: Proposed Improvement for Cylinder Sleeves:

For technology card no 322474 given timings: 50:09 (Hr:Min)

\begin{tabular}{|l|l|l|l|}
\hline \multirow{2}{*}{ S.No. } & $\begin{array}{l}\text { Proposed Im- } \\
\text { provement }\end{array}$ & $\begin{array}{l}\text { List of actions can be } \\
\text { eliminated }\end{array}$ & $\begin{array}{l}\text { Given tech- } \\
\text { nology time } \\
\text { Hr: Min }\end{array}$ \\
\hline \multirow{2}{*}{1} & $\begin{array}{l}\text { Buying pipe } \\
\text { available in mar- } \\
\text { ket, will reduce } \\
\text { certain operation }\end{array}$ & Turning Op 1 & $\begin{array}{l}\text { Inner-Surface Finishing } \\
\text { (Honing) }\end{array}$ \\
\cline { 3 - 4 } & Turning Operation 4 & $10: 30$ \\
\hline \multicolumn{2}{|l|}{ Total time saving } & $46: 12$ & $13: 12$ \\
\hline
\end{tabular}

Based on cost:

\begin{tabular}{|l|l|l|l|}
\hline \multirow{2}{*}{ S.No. } & \multirow{2}{*}{ Action / Task } & $\begin{array}{l}\text { List of action } \\
\text { cost }\end{array}$ & $\begin{array}{l}\text { Calculated Cost } \\
\text { (Rs.) }\end{array}$ \\
\hline \multirow{4}{*}{1} & & Forging & 158906 \\
\cline { 3 - 4 } & \multirow{3}{*}{$\begin{array}{l}\text { Cost with respect } \\
\text { to existing plan }\end{array}$} & Turning & 23014 \\
\cline { 3 - 4 } \cline { 3 - 4 } $\begin{array}{l}\text { Current } \\
\text { Total Price }\end{array}$ & & Toning & 15705 \\
\cline { 3 - 4 } & & & 12614 \\
\hline
\end{tabular}

Pipe price available in market: Rs 102153 (New Proposal)

Savings from the above proposed improvement

$=$ Rs 108086

\section{Step 6.2: Propose Improvement For Piston Rods:}

Total time given $(\mathrm{Hr}: \mathrm{Min})=92: 46$

\begin{tabular}{|l|l|l|l|}
\hline S.No. & $\begin{array}{l}\text { Proposed im- } \\
\text { provement }\end{array}$ & List of actions can be eliminated & $\begin{array}{l}\text { Given } \\
\text { time } \\
\text { Hr:Min }\end{array}$ \\
\hline 1 & Buying heat & Cutting the rod & $0: 18$ \\
\hline
\end{tabular}




\begin{tabular}{|l|l|l|l|}
\hline \multirow{4}{*}{$\begin{array}{l}\text { Treated Rod } \\
\text { without chrom- } \\
\text { ing coating } \\
\text { (New Pro- } \\
\text { posal) }\end{array}$} & $\begin{array}{l}\text { Smoothing- after cutting pro- } \\
\text { cess }\end{array}$ & $0: 18$ \\
\cline { 2 - 3 } & Initial drilling & $1: 12$ \\
\cline { 2 - 3 } & Turning / Heat treatment & $0: 48$ \\
\cline { 2 - 3 } & Preparation for co-operation & $0: 18$ \\
\cline { 2 - 3 } & Preparation for co-operation & $0: 54$ \\
\cline { 2 - 3 } & Cut a portion of rod & $0: 21$ \\
\cline { 2 - 3 } & Turning & $18: 0$ \\
\cline { 2 - 3 } & Heat treatment & $15: 06$ \\
\hline
\end{tabular}

\section{Cost Reduction:}

\section{Current Price}

\begin{tabular}{|l|l|l|}
\hline S.No. & \multicolumn{1}{|c|}{ List of action cost } & Calculated Cost (Rs.) \\
\hline 1 & Cost of rod & 38650 \\
\hline 2 & Heat treatment cost & 38135 \\
\hline 3 & Transport to heat treatment & 15692 \\
\hline 4 & Quality check & 30507 \\
\hline 5 & Chroming coating & 59490 \\
\hline 6 & Transport to chroming coating & 16970 \\
\hline 7 & Machining cost (manual op) & 38096 \\
\hline \multicolumn{2}{|l|}{ Current Total price } & 238818 \\
\hline
\end{tabular}

\section{Price after Improvement}

\begin{tabular}{|l|l|l|}
\hline S.No. & \multicolumn{1}{|c|}{ List of action cost } & \multicolumn{1}{c|}{$\begin{array}{c}\text { Calculated cost } \\
\text { (Rs.) }\end{array}$} \\
\hline 1 & Cost of rod & 51120 \\
\hline 2 & Chroming coating & 59490 \\
\hline 3 & Transport to chroming & 16970 \\
\hline 4 & Machining & 38096 \\
\hline \multicolumn{2}{|l|}{ Total price With proposed improvement } & $\mathbf{1 6 5 6 7 6}$ \\
\hline
\end{tabular}

Savings $=$ Rs. 73142 per Unit

\section{Step 6.3: Conclusion on Selected Jobs:}

$\checkmark \quad$ Total time can be saved from new proposal (hr:min) $-83: 27$

$\checkmark \quad$ Total cost saving from new proposal for cylinder and piston rod of hydraulic cylinders

$\checkmark$ Total cost saving $\quad=\quad$ Rs. 181228

\section{Conclusion and Summary}

Kaizen 10 step methodology was successfully implemented and the total cost of hydraulic cylinder has been reduced drastically. The improved proposal is presented here. An update requires with current technologist work plan preparation, this will optimize overall timing for each operation, which leads to improvement in cost. These updates are possible only by standardizing some technical procedures.

Solution 1: Technical standards and grades

In our above selected BPCS the material grade 200-220 HB is selected for cylinder.

Key reason: Here,

- The cost of cylinder with grade $200-220 \mathrm{HB}$ in market is low compared to our regular procedure to produce a cylinder.

- But the grade varies with each orders i.e. between from $200-$ $360 \mathrm{HB}$ - This has to technically verified.

- When we standardize the grade level to $220 \mathrm{HB}$, we can skip some major operations which are being done externally.

- Technical standardization also includes other area like, chroming coating, piston rod.

Solution 2: Specific clients

- Delay on client approval on costing
- This delays our delivery date and occupies our space at work shop.

Key reason: Here, we need to discuss with client to improve their approval speed. Or need to know the reason of delay

\section{Solution 3:}

Technical work Comparison has to done between our procedure of servicing and other marketers (internally AMP).

Key reason: Operational improvements (can reduce manual operation timing)

\section{Solution 4:}

Increase no of orders from client and find more clients. The implementation of above mentioned solution number 1,3 and 4 will improve Efficiency.

\section{References}

[1] Adam Paul Brunet \& Steve New, "Kaizen in Japan: an empirical study", International Journal of Operations \& Production Management, Vol. 23, No. 12, (2003), pp. 1426-1446.

[2] Amit Kumar Arya \& Sanjiv Kumar Jain, "Impacts of Kaizen in a small-scale industry of India”, International Journal of Lean Six Sigma, Vol. 5, No. 1, (2013), pp. 22-44.

[3] Bauyrzhan Aimukhanbetuly Aimukhanbet \& Vitaly Vasilyevich Povetkin, "The Production Method of High Pressure Hydraulic Cylinders", Modern Applied Science, Vol. 9, No. 2, (2015), pp. 3041 .

[4] G. Wittenberg, "Kaizen - The Many Ways of Getting Better", Assembly Automation, Vol. 14, No. 4, (1994), pp. 12-17.

[5] JrJung Lyu, "Applying Kaizen and Automation to Process Reengineering”, Journal of Manufacturing Systems, Vol. 15, No. 2, (1996)

[6] Juli Ratnawati, Kusni Ingsih \& Imam Nuryanto, "The implementation of kaizen philosophy to improve industrial productivity", IJABER, Vol. 14, No.2, (2016), pp. 1343-1357.

[7] Manjunath Shettar, Pavan Hiremath, Nikhil R \& Vithal Rao Chauhan, "KAIZEN", Int. Journal of Engineering Research and Applications ISSN: 2248-9622, Vol. 5, No. 5, (2015).

[8] Matilda Hook \& Lars Stehn, "Lean principles in industrialized housing production: The need for a cultural change", Lean Construction Journal, (2008), pp. 20-33.

[9] R.Suganthini Rekha, P.Periyasamy \& S.Nallusamy, "Manufacturing Enhancement through Reduction of Cycle Time using Different Lean Techniques", IOP Conf. Ser.: Mater. Sci. Eng. 225 012282, (2017).

[10] Rajesh Gautam, Sushil Kumar \& Sultan Singh, "Kaizen Implementation in an Industry in India”, IJRMET, Vol. 2, (2012).

[11] V. Gomez Rodriguez, Juan José Cabello Eras, Hernan Hernandez Herrera \& Rafael Goytisolo Espinosa, "Static analysis of a hydraulic cylinder", International Journal of Engineering and Technology, (2017).

[12] Valerio Morra, "The "Kaizen" project improves production efficiency”, Mcc Magazine Technical Info Journal, (2014). 